\title{
Correspondence
}

ChINA \& WTO ReV. 2019:1; 149-166

http://dx.doi.org/10.14330/cwr.2019.5.1.07

pISSN $2383-8221 \cdot$ elSSN $2384-4388$

China and WTO Review

\section{Digitalization of Trade in Free Trade Agreements with Reference to the WTO and the USMCA: A Closer Look}

\author{
Bashar H. Malkawi*
}

Millions of people worldwide use the Internet. One of the many uses derived from the Internet is the development of digital trade. Digital trade thus lends itself to distinctive issues. The WTO members recognized the benefits digital trade offers and have developed a work program to facilitate the digital trade. However, their efforts have stalled, slowing down the anticipated progress. The author will try to address how the WTO supports and deals with digital trade. This essay briefly discusses the historical advancement of the Internet; defines the concept of digital trade and its development in the international market; analyzes how existing WTO agreements have dealt with digital trade; and then addresses recent trade agreements particularly the USMCA. The USMCA was chosen because it involves the largest economy in the world and the US could use its provisions as template for future trade agreements

Keywords: USMCA, WTO, Digitalization of Trade, FTA, Internet

* Dean and Professor of Law at the University of Sharjah, UAE. LL.B.(Yarmouk Univ.), LL.M. (Arizona), S.J.D. (AU). ORCID: https://orcid.org/0000-0003-2009-1619. The author may be contacted at: bmalkawi@gmail.com / Address: University of Sharjah, College of Law, P.O. Box 27272-Sharjah, United Arab Emirates. 


\section{Introduction}

Digital trade offers economy-wide benefits. ${ }^{1}$ The advancement of technology has aided international business transaction. Millions of people worldwide use the Internet to do everything from research to purchasing products online. One of the many uses derived from the Internet is the development of digital trade. Digital trade thus lends itself to distinctive issues. The World Trade Organization ("WTO") members recognized the benefits digital trade offers and have developed a work program to facilitate the digital trade. However, their efforts have stalled, slowing down the anticipated progress.

The author will try to address how the WTO supports and deals with digital trade. This essay briefly discusses the historical advancement of the Internet; defines the concept of digital trade and its development in the international market; analyzes how existing WTO agreements have dealt with digital trade; and then addresses recent trade agreements particularly the USMCA. The USMCA was chosen because it involves the largest economy in the world and the US could use its provisions as template for future trade agreements. ${ }^{2}$

\section{A. Development of the Internet}

The rise of digital trade is due to the Interne revolution, which has evolved from a tool of communication to one of economic utilities. The Internet facilitates electronic business transactions both nationally and internationally by permitting businesses to have easy access to large consumer bases at lower costs.

The modern structure of the Internet developed from a US Army experiment more than thirty years ago. ${ }^{3}$ The term Internet derived from the terms 'interconnection' and 'network.' It meant the "network formed by the cooperative interconnection of computing networks." Today, the Internet exists in no physical realm. Instead, it is a giant network which interconnects innumerable smaller groups of linked computer networks, ${ }^{5}$ referred to as the World Wide Web (www). The Internet has the ability to disseminate information to a large number of people quickly with minimum costs. ${ }^{6}$ Because of the inexpensive nature of the Internet, the start-up cost to a company desiring to have a place on the Internet is minimal.

In its early inception, the Internet was used mainly as a tool for people to communicate with one another through e-mail or in chat rooms. Early utilization 
of the Internet for business focused mainly on direct business to consumer transactions. Some businesses, realizing the risk of surviving in the Internet environments, have moved away from consumer based transactions to the business to business ("B2B") model which means the use of the Internet by one business to market his product to another business.

\section{B. Importance of Digital Trade in the Global Market}

Digital trade can be defined as the "use of the Internet to conduct business transactions nationally or internationally." ${ }^{8}$ Now, the Internet is profoundly affecting almost all businesses. The various uses of the Internet by business entities include the ability to advertise, generate, or otherwise perform regular business functions. Therefore, many firms are embracing the Internet for most of their activities.

Numbers can indicate the importance of the digital trade boom. In 2017, global digital trade was worth over USD 2090 billion. ${ }^{9}$ Around eighty percent of those transactions were between one business and another. The influence of digital trade stretches farther. It is used more as a trading system in which buyers and sellers could establish a genuine market price.

Traditional companies cannot ignore the importance of digital trade. Most companies must become e-firms if they are to survive. However, merely adding a website to an existing business is not enough. The whole business for companies needs to be redesigned around the cost-saving, communication-easing properties of the net. One impact for digital trade is thus to intensify competition and producing benefits to consumers in lower prices and more choices.

\section{WTO and Digital Trade}

Digital trade has developed since the creation of the WTO in 1995. Consequently, the WTO does not contain specific articles for digital trade. Nevertheless, there are several WTO agreements related to digital trade including the General Agreement on Trade in Services ("GATS") and the Information Technology Agreement ("ITA"). 


\section{A. GATS}

The GATS is of particular significance to digital trade for several reasons. First, the communication services which provide access to digital trade fall under the GATS. ${ }^{10}$ Second, the GATS covers many sectors and modes of delivery whether the mode is traditional or electronic. Indeed, it was determined that the GATS was technologically neutral. ${ }^{11}$ Third, the execution of an electronic transaction necessitates infrastructure services (distribution, payment, etc.) whose liberalization equally falls under the GATS. In view of the acknowledged importance of telecommunication services, the access to public telecommunication networks was incorporated into a separate telecommunication annex. ${ }^{12}$

Each WTO member agreed to liberalize specific service sectors. These commitments are included in schedules or lists of service commitments. These commitments range from liberalizing education, tourism, insurance, media, auditing, legal services, and other areas. In other words, what is covered and not covered a WTO member schedule of service depends on the particulars of that country. ${ }^{13}$ Many service sectors can be delivered physically and more importantly electronically. Whenever unlimited market access commitments are undertaken, every means of delivery including remote supply should be allowed. ${ }^{14}$

Article VI of the GATS authorizes the Council for Trade in Services to develop the necessary disciplines to ensure that measures relating to qualification requirements and procedures, technical standards and licensing requirements do not constitute unnecessary barriers to trade in services. ${ }^{15}$ This language applies to digital trade. The WTO members should not adopt policies or measures that are more burdensome than necessary to ensure quality of the service. They agreed to so-called Reference Paper, which would provide for the rules that shall prevent anti-competitive behavior in the telecommunications sector. ${ }^{16}$ The Reference Paper includes competition policy principles to ensure access to public telecommunication networks. The WTO members considered that the Reference Paper might be applicable to digital services where Internet access providers qualify as major suppliers of basic telecommunications. ${ }^{17}$ The EU opined that the principles of the Reference Paper should be applicable to internet access and internet network services. ${ }^{18}$ 


\section{B. ITA}

The ITA is of a particular significance to digital trade. The WTO members agreed to a common position with regard to trade in information technology ("IT") goods. They committed themselves to reduce their tariffs on IT-goods in four steps of twenty-five percent to reach a tariff-free policy by the year $2000 .{ }^{19}$ This obligation pertains to a common list of IT-products covering wide range of some 180 IT products in five major categories: computers and peripheral devices, semiconductors, printed circuit boards, telecommunications equipment (except satellites), and software. ${ }^{20}$ By the year 2015, the ITA had covered ninety-five percent of the existing world trade in IT-goods. ${ }^{21}$ Thus, the ITA brings advantages to a wide range of production activities.

Largely at the insistence of the US at the WTO Ministerial Conference in 1998, the WTO members decided to develop a work program covering digital trade. $^{22}$ According to the WTO Work Program on Electronic Commerce, digital trade is understood to mean the production, distribution, marketing, sale or delivery of goods and services by electronic means. ${ }^{23}$ The WTO divides digital trade transactions into three distinctive stages: the advertising and searching stage, the ordering and payment stage, and the delivery stage. ${ }^{24}$ Any or all of these stages may be carried out electronically so that they may be covered by the concept of digital trade. In other words, a buyer may purchase a book via the Internet and to be delivered physically later on or he can purchase and download the book via the Internet. In either case, the purchase of the book could conducted through digital trade means.

Despite the establishment of the WTO Work Program on Electronic Commerce up in 1998, very little progress has been achieved. The most important issue blocking progress on digital trade in the WTO agenda is the question of categorization. The WTO members have different opinions whether products which were usually sold as 'goods' due to their link to a physical carrier and which can now be delivered online over the net (e.g., music or movies) shall be treated as goods under the General Agreement on Tariffs and Trade ("GATT") or as 'services' under the GATS. ${ }^{25}$ For example, if a book is ordered online, but delivered physically, for the purposes of the WTO trade rules, it is a good. That makes it subject to the GATT. However, if the book is delivered electronically downloaded onto the computer - it is unclear whether this digital product should 
be treated as a good or a service. If goods delivered online were considered goods, they would be subject to few trade restrictions under the GATT such as tariffs. ${ }^{26}$ On the other hand, if goods delivered online were considered services, they would be subject to more trade restrictions under the GATS such as market access barriers and discriminatory domestic regulations. ${ }^{27}$ For example, if the delivery of films and broadcasts on the Internet is considered services, each member would apply its restrictive rules on the distribution and broadcast of audiovisual works to films and television programs transmitted over the Internet. Until the classification debate is resolved, the WTO members decided not to impose tariffs on imported electronic transmissions. ${ }^{28}$

There were numerous WTO meetings and seminars producing views and proposals which are reflected in the country statements or the final reports. ${ }^{29}$ These meetings would include more informal exchange of viewpoints than the achievement of agreements. Therefore, the classification debate issue continues to be unresolved. ${ }^{30}$ There have been no new digital trade relevant actions at the WTO until now.

\section{WTO Case Law and Digital Trade}

The WTO first addressed digital trade through its ruling on the US restrictions on cross-border Internet gambling services. In United States - Measures Affecting the Cross-Border Supply of Gambling and Betting Services, Antigua and Barbuda claimed that the US Internet gambling restrictions by the US credit card companies on payments to offshore gambling outlets, at both the federal and state levels violated the US commitments under the GATS. ${ }^{31}$ Antigua claimed to have lost some USD 90 million over the period 2000-04 as a result of the restrictions in the US, its principal market, reducing the number of Internet gambling enterprises in Antigua from 119 to 30 in the same period. ${ }^{32}$

A WTO panel ruled that online gambling restrictions imposed by the US at the federal and state levels violated its market access commitments under subsector 10.D (other recreational services) of its GATS schedule. ${ }^{33}$ In particular, the WTO panel agreed with Antigua that US market access commitments under Section 10.D of its GATS schedule covering "other recreational services" do include gambling services. ${ }^{34}$ The panel rejected the US claim that it never intended to allow the cross-border supply of such services. ${ }^{35}$ The panel also maintained that 
the US commitment to allow unrestricted market access on recreational services applies to all means of delivery, including the Internet. ${ }^{36}$ While the WTO panel agreed with the US that the US ban on cross-border gambling services may be justified under the WTO rules to protect 'public morals,' it found that the ban was applied in a discriminatory manner since the US permits remote gambling wagers through off-track betting under the 1978 Interstate Horseracing Act. ${ }^{37}$

In China - Publications and Audiovisual Products, the WTO panel found that the scope of China's commitment in its GATS Schedule on "sound recording distribution services" extends to sound recordings distributed in non-physical form through technologies such as the Internet. ${ }^{38}$ In achieving this outcome, the WTO panel relied on the principle of progressive liberalization which contemplates that the WTO Members undertake specific commitments through successive rounds of multilateral negotiations with a view to liberalizing their services markets incrementally. ${ }^{39}$ Thus, distribution covers both tangible and intangible products.

Prior to the WTO panel's findings in those disputes, neither WTO panel nor the Appellate Body has ever decided a digital trade case. The WTO's ruling would have important implications, notably in the relationship between the WTO and digital trade. Today, under the WTO jurisprudence digital trade is covered under the GATS.

\section{The Digital Trade Provisions in the USMCA}

The US-Mexico-Canada [Free] Trade Agreement ("USMCA") explicitly includes provisions concerning digital trade. ${ }^{40}$ The digital trade provisions of the USMCA - which resemble the language in the Trans-Pacific Partnership ("TPP") - apply to goods and services traded over the medium of the Internet. ${ }^{41}$ The USMCA ensures that both physical and downloaded software are treated the same.

The USMCA provides a definition for digital products. A digital product means a computer program, text, video, image, sound recording, or other product that is digitally encoded, produced for commercial sale or distribution, and that can be transmitted electronically. ${ }^{42}$ The USMCA provides illustrative examples of digitized products such as electronically traded software, books, and music. ${ }^{43}$

The entire purpose of this FTA is to lower barriers to trade in all sectors, including digital trade. Therefore, the US, Mexico, and Canada were in the 
position with digital trade to never even establish a tariff that would later need to be lowered and eliminated. ${ }^{44}$ The USMCA creates duty-free cyberspace, which requires parties not to impose customs duties on electronic transmissions. This language is based on the US Internet Tax Freedom Act of $1998 .^{45}$ The customs duties standstill in the USMCA is not indefinite or permanent. The parties to the agreement are merely obliged to continue the customs duties standstill until further notice.

The continuing of the no-duty policy under the USMCA may result in negative economic impact on, for example, Mexico because it would not collect the tariff from digital transactions, but from other transactions that actually result in the payment of tariffs. The other economic implication for no-duty policy under the USMCA is that it could lead to trade-diversion because of the preferential treatment of a particular mode of delivery over other modes. The USMCA language is limited to tariffs but not domestic taxes whether directly or indirectly. As a result, the US could impose taxes on seller's income based on his/her economic activity. Mexico or Canada can impose value added taxes on some transactions, especially for tangible goods above a certain value. However, any domestic taxation of digital trade could be limited and done in a way which ensures neutral treatment between supply modes.

The USMCA also requires that the parties not establish unnecessary barriers on electronic transmissions. ${ }^{46}$ The term 'unnecessary' is not clearly understandable. In addition, the standard 'unnecessary barriers' is subjective since each party will determine what a necessary or unnecessary barrier is. An example of 'unnecessary barrier' could be applying trade restrictive technology mandates and not using open and market-driven standards. Applying trade restrictive technology mandates could inhibit the growth of digital trade. ${ }^{47}$

The USMCA is concerned with the delivery of services electronically. As such, this FTA not only covers trade in goods electronically, but also trade in services. For instance, a supplier in the US could deliver financial services, engineering plans, or legal services, to a client in Mexico through the Internet. In this case, however, it is unclear how the delivery mode could be classified and whether it is virtual cross-border supply or consumption abroad.

The USMCA does not require harmonization of digital trade laws and regulations of the member States. The absence of such harmonization could pose 
problems for trading in products electronically when countries have different levels of laws and regulations. However, since the nature of the Internet and digital trade is global, an international approach is then needed for regulating digital trade.

The USMCA contains several principles that deal with technological neutrality. It ensures that basic trade concepts of non-discrimination, national treatment, and most-favored-nation status apply to digital trade, and regulatory forbearance, i.e., avoiding government action that would restrict trade. The USMCA also covers the validity of electronic signatures. ${ }^{48}$

The USMCA has yet to determine if digital products should be treated as goods, services, or something new altogether. Determining whether an e-product is a good or service is a crucial assessment. If an e-product is a good, it will then be subject to the national treatment rules. In contrast, if an e-product is a service, each party may impose restrictions on market access and national treatment. Moreover, the digital trade provisions of the USMCA apply to digitized products traded only between the parties. However, considering the global nature of digital trade, it might be difficult to determine whether the product is of a US or Mexican origin for purposes of the trade agreement.

The USMCA provides that no country is allowed to give less favorable treatment to digital products "created, produced, published, contracted for, commissioned or first made available on commercial terms in the territory of another party, or to digital products of which the author, performer, producer, developer or owner is a person of another party." ${ }^{, 49}$ Moreover, it allows the parties to provide subsidies or grants to its own residents and businesses, including "government-supported loans, guarantees and insurance." give the parties some policy space whereby they can favor their domestic cultural industries.

The USMCA requires to maintain anti-spam rules and online consumer protection laws. ${ }^{51}$ However, these rules do not contain any specificity. The same is true for personal information protection requirements, ${ }^{52}$ which call for a legal framework to protect the personal information of digital trade users. However, an acknowledgment is buried in a footnote that merely enforcing voluntary undertakings of enterprises related to privacy is sufficient to meet the obligation. The USMCA information protection requirements do not establish a mandatory 
minimum of protection. ${ }^{53}$

Paperless trade did not escape the attention of the USMCA negotiators as it would help to facilitate trade. ${ }^{54}$ Each party endeavors to accept a trade administration document submitted electronically as the legal equivalent of the paper version of that document. Although the language used is not strong as it refers to 'endeavors,' but is still important to include it to ensure faster movements of goods and services across borders. ${ }^{55}$

The USMCA include targeted sections on computer facilities. ${ }^{56}$ The purpose of such provision is to prevent maintaining control over information processing and storage in a country. Thus, the parties to the USMCA would not make it a condition for conducting business that a company from a trading partner must use or locate a computing facility in their country. The USMCA does not provide for public policy objectives which may lead party to require the physical presence of computing facilities in certain circumstances. ${ }^{57}$

The USMCA recognizes that there are different legal approaches to protecting personal information, including comprehensive privacy, personal information, or personal data protection laws; sector-specific laws covering privacy; or laws that provide for the enforcement of voluntary private sector undertakings. The US, Canada, and Mexico agreed to promote compatibility and exchange information on their respective mechanisms. The USMCA specifically identifies the APEC Cross-Border Privacy Rules system as a valid mechanism to facilitate cross-border information transfers while protecting personal information. ${ }^{58}$

The USMCA includes provisions to break down data localization laws, which require that certain kinds of data remain within a country's borders. The USMCA bans restrictions on data transfers across borders. ${ }^{59}$ Conversely, the EU demands limits on data transfers. ${ }^{60}$ The European model of data protection uses data transfer restrictions as a way to ensure adequate legal protections for the information. ${ }^{61}$

The USMCA prevents countries from requiring the disclosure of source code. ${ }^{62}$ In addition, it goes further to bar governments from requiring the disclosure of 'algorithms' expressed in that source code unless the disclosure was required by a regulatory body for a specific investigation, inspection, examination enforcement action or proceeding. ${ }^{63}$

The USMCA stipulates the protection for Internet service providers modeled on the Digital Millennium Copyright Act. ${ }^{64}$ It protects Internet service providers 
for copyright liability for the actions of their users. Internet platforms are not held civilly - but not criminally - liable for the actions of their users. However, the USMCA does not provide a balanced approach to copyright which might have further empowered user rights.

The USMCA protects open government data provided in machine readable format. ${ }^{65}$ The language used regarding open government date is not mandatory but rather best endeavors.

\section{Conclusion}

The Internet offers substantial opportunities to companies. The world has witnessed an explosion in digital trade for the past few years, with online shopping now doubling annually. Although the WTO did not contain explicit articles covering digital trade, the WTO seems to be well-fitted to advance digital trade because of its principles of non-discrimination, transparency, and market openness. However, the WTO program on digital trade is stalled because the WTO members could not agree on the so-called horizontal issues such as whether products delivered in digital form should be classified as goods or services under the WTO rules.

The USMCA was considered as a breakthrough to the WTO deadlock in the sense that it included explicit chapter concerning digital trade. A closer examination of the USMCA on digital trade revealed that the parties invent some specific rules for digital trade. Due to most of the digital trade provisions in the USMCA, the parties were approaching based on the simple premise that digital trade is trade, but the medium of delivering goods and service is different i.e. being delivered online. Therefore, the USMCA does not require many legal changes to domestic laws.

The digital trade provisions in the USMCA showed the need to push the debate over digital trade forward. Future trade agreements should expand existing trade rules or draw up new rules. There is a host of digital trade issues that need to be addressed in future trade agreements. They are including new technologies such as block chain, classification of the content of certain electronic transmissions, the issue of 'likeness' of e-goods; development-related issues, such as access to infrastructure and technology; fiscal and revenue implications of digital trade; the 
relationship and possible substitution effects between digital trade and traditional forms of commerce; and whether dispute settlement mechanism covers digital trade in a way similar to any other provision in the free trade agreement. By expanding and developing rules for digital trade, the USMCA parties can take maximum advantage of the vast opportunities that the technological revolution offers.

\section{REFERENCES}

1. Digital trade and e-commerce can be used interchangeably. Both terms refer to the trade of goods and services using the Internet including the transmission of information and data across borders. However, digital trade has wider connotation such as big data, Internet of things, and clouding. Thus, 'digital trade' will be utilized throughout the article.

2. Earlier free trade agreements have included e-commerce chapters since the 2001 USJordan FTA. However, the e-commerce provisions can be limited to goods sold online. See B. Bieron \& U. Ahmed, Regulating E-commerce through International Policy: Understanding the International Trade Law Issues of E-commerce, $46 \mathrm{~J}$. WORLD TRADE 551 (2012). See also M. Ptashkina, Facilitation 2.0: E-Commerce and Trade in the Digital Age 7-8 (2018), available at https://www.ictsd.org/sites/default/files/research/rta exchange_-_ptashkina_-_facilitation_2.0_-_e-commerce_-_ptashkina_0.pdf (last visited on Jan. 19, 2019).

3. 47 U.S.C. $§ 230(\mathrm{e})(1)$ (Supp. 1998).

4. G. Cady \& P. McGregor, Mastering the Internet 5 (2d. ed. 1996).

5. Reno v. ACLU, 117 U.S. 2329, 2334 (1997).

6. D. Cielusniak, You Cannot Fight What You Cannot See: Securities Regulation on the Internet, 22 FoRdHAM InT'L L.J. 612-6 (1998).

7. B. Schaefer, International Taxation of Electronic Commerce Income: A proposal to utilize software agents for source-based taxation, 16 Santa Clara Computer \& High Tech. L. J. 111-20. (1999)

8. See Study from WTO Secretariat highlights potential trade gains from electronic commerce, WTO News, (Mar. 13, 1998), available at https://www.wto.org/english/news e/pres98_e/pr96_e.htm (last visited on Jan. 19, 2019).

9. See Global E-Commerce Trends and Statistics, AmastyBlog, Jan. 29, 2018, available at 
https://amasty.com/blog/global-e-commerce-trends-and-statistics-2017-2018 (last visited on Jan. 19, 2019).

10. T. McLarty Liberalized Telecommunications Trade in the WTO: Implications for Universal Service Policy, 51 Fed. Сомм. L. J. 1-7 (1998).

11. Panel Report, US - Gambling, ๆ 6.285, WTO Doc. WT/DS285/R, (adopted Nov. 10, 2004), available at https://docs.wto.org/dol2fe/Pages/FE_Search/FE_S_S009-DP.aspx?1 anguage $=\mathrm{E} \&$ CatalogueIdList $=73463 \&$ CurrentCatalogueIdIndex $=0 \&$ FullTextHash $=\& H$ asEnglishRecord=True \&HasFrenchRecord=True \&HasSpanishRecord=True (last visited on Jan. 19, 2019).

12. The Telecommunication Annex states that any service supplier of any other WTO member must be accorded access to and use of public telecommunication networks and services on reasonable and non-discriminatory terms and according to conditions for the supply of a service included in the country schedule. See Telecommunication Annex 5(a).

13. R. Zhang, Covered or Not Covered: That Is the Question - Services Classification and Its Implications for Specific Commitments under the GATS (WTO Staff Working Paper, No. ERSD-2015-11, 2015), available at file://C:/Users/user/AppData/Local/Microsoft/ Windows/INetCache/IE/3ILT3G2Q/845007270.pdf (last visited on Jan. 19, 2019).

14. Appellate Body Report, US - Gambling, I 239, WTO Doc. WT/DS285/AB/R (adopted Apr. 7, 2005), available at https://docs.wto.org/dol2fe/Pages/FE_Search/FE_S_S006. aspx?Query=(@Symbol=\%20wt/ds285/ab/r*\%20not\%20rw* $) \& L a n g u a g e=E N G L I S H$ $\&$ Context=FomerScriptedSearch\&languageUIChanged=true\# (last visited on Jan. 19, 2019).

15. GATS art. VI(4), available at https://www.wto.org/english/tratop_e/serv_e/dom_reg_ negs_e.htm (last visited on Jan. 19, 2019).

16. The non-discriminatory, transparent access and interconnection with the public network or dominant supplier are obligatory. Even though each country has the right to maintain domestic regulations concerning universal service obligations, this right shall be used in a fair and non-discriminatory manner. Not only the allocation of licenses but also the award of other scarce resources (numbers, frequencies, etc.) shall be fair and non-discriminatory. The Reference Paper demands the establishment of an independent regulatory agency which must supervise the observance of the above principles and the telecom markets in general.

17. WTO Council for Trade in Services, Work Programme on Electronic Commerce Progress Report to the General Council, Adopted by the Council for Trade in Services on 19 July 1999, S/L/74, July 27, 1999, ๆ 13, available at https:/docs.wto.org/dol2fe/Pages/ FE_Search/FE_S_S009-DP.aspx?language $=$ E\&CatalogueIdList $=32179 \&$ CurrentCatalog ueIdIndex $=0 \&$ FullTextHash $=371857150 \&$ HasEnglishRecord $=$ True \&HasFrenchRecord $=$ True\&HasSpanishRecord=True (last visited on Jan. 19, 2019).

18. WTO Council for Trade in Services, Work Programme on Electronic Commerce, 
Communication from the European Communities and their Member States, S/C/W/183, 30 Nov. 30, 2000, ๆ 6, available at https://docs.wto.org/dol2fe/Pages/FE_Search/FE_S_ S009-DP.aspx language $=E \&$ CatalogueIdList $=713 \&$ CurrentCatalogueIdInde $=0 \&$ FullTe $\mathrm{xtHash}=371857150 \&$ HasEnglishRecord $=$ True \&HasFrenchRecord=True \&HasSpanishRe cord=True (last visited on Jan. 19, 2019).

19. C. Verrill, Jr. \& P. Jordan \& T. Brightbill, International Trade, 32 InT'L Law. 319-24 (1998).

20. WTO, 15 Years of the Information Technology Agreement: Trade, Innovation, and Global Productions Networks 11 (2012), available at file://C:/Users/user/AppData/ Local/Microsoft/Windows/INetCache/IE/3ILT3G2Q/799_15_years_of_.pdf (last visited on Jan. 19, 2019).

21. WTO, 20 Years of the Information Technology Agreement, available at https://www. wto.org/english/res_e/booksp_e/ita20years_2017_chap2_e.pdf (last visited on Jan. 19, 2019).

22. Four WTO subsidiary bodies had been charged with examining e-commerce issues: the Goods Council, the Services Council, the TRIPS Council and the Committee on Trade and Development. See WTO, Development Implications of Electronic Commerce, WTO Doc. T/COMTD/w/51 (adopted Nov. 23, 1998), available at https://ocs.wto.org/dol2fe/ Pages/FE_Search/FE_S_S009-DP.aspx?language $=$ E\&CatalogueIdList $=1$ 14907,459,287 $40,30467 \&$ CurrentCatalogueIdIndex $=3 \&$ FullTextHash $=\&$ HasEnglishRecord $=$ True $\&$ Has FrenchRecord $=$ True \&HasSpanishRecord=True (last visited on Jan. 19, 2019).

23. WTO, Electronic Commerce, available at https:/www.wto.org/english/tratop_e/ecom_e/ ecom_e.htm (last visited on Jan. 19, 2019).

24. WTO Committee on Trade and Development, Development Implications of Electronic Commerce, WTO Doc. WT/COMTD/W (adopted Nov. 23, 1998), available at file:// C:/Users/user/AppData/Local/Microsoft/Windows/INetCache/IE/4HUAGB07/W51.pdf (last visited on Jan. 19, 2019).

25. K. Bergemann, A Digital Free Trade Zone and Necessarily-Regulated Self-Governance for Electronic Commerce: The World Trade Organization, International Law, and Classical Liberalism in Cyberspace, 20 Marshall J. Comput. \& Information L. 595-601 (2002).

26. The US advocates that products delivered online should be classified as 'goods,' while the EU counters that all products delivered electronically should be considered 'services.' See S. Baker et al., E-Products and the WTO, 35 InT'L Law. 5-7 (2001).

27. When an electronic transaction falls under the GATS, one must decide under what GATS mode the service is to be registered. The GATS describes several modes for service delivery. In the case of electronic transaction, it is a point at issue if it shall be under mode 1 (cross-border trade) where a service is exported from one member of the WTO to another member or mode 2 (consumption abroad) where the service is consumed in the country of 
origin of the service supplier but is consumed by a customer of a different nationality.

28. WTO Council for Trade in Goods, Minutes of the Meeting of the Council for Trade in Goods, WTO Doc. G/C/M/127 (Nov. 17, 2016), available at https:/docs.wto.org/dol2fe/ Pages/FE_Search/FE_S_S009-DP.aspx?language $=$ E\&CatalogueIdList $=248609,243969,2$ 40057,239646,238799,235037,232274,229893,229894,228104\&CurrentCatalogueIdInde $\mathrm{x}=5 \&$ FullTextHash $=1 \&$ HasEnglishRecord $=$ True \&HasFrenchRecord $=$ True \&HasSpanish Record=True (last visited on Jan. 19, 2019).

29. WTO Committee on Trade and Development, Seminar on Electronic Commerce and Development, 19 February 1999, WTO Doc. WT/COMTD/18 (adopted Mar. 23, 1999), available at https://docs.wto.org/dol2fe/Pages/FE_Search/FE_S_S009-DP.aspx?languag $\mathrm{e}=\mathrm{E} \&$ CatalogueIdList $=117618,2749,33968 \&$ CurrentCatalogueIdIndex $=2 \&$ FullTextHas $\mathrm{h}=\&$ HasEnglishRecord=True $\&$ HasFrenchRecord $=$ True $\&$ HasSpanishRecord $=$ True $($ last visited on Jan. 19, 2019).

30. WTO, Works Continue on Issues Needing Clarification, available at https://www.wto. org/english/tratop_e/ecom_e/ecom_briefnote_e.htm. See also South Centre Analytical Note, The WTO's Discussions on Electronic Commerce, SC/AN/TDP/2017/2 (Jan. 2017), available at https://www.southcentre.int/wp-content/uploads/2017/01/AN_ TDP_2017_2_The-WTO\%E2\%80\%99s-Discussions-on-Electronic-Commerce_EN-1. pdf (all last visited Jan. 23, 2019).

31. Panel Report, United States-Measures Affecting the Cross-Border Supply of Gambling and Betting Services, WTO Doc. WT/DS285/R, ๆ 2.1 (adopted Nov. 10, 2004), available at http://www.worldtradelaw.net/reports/wtopanels/us-gambling(panel).pdf (last visited on Jan. 19, 2019).

32. A. Lumsden, Blowing the Dice: Hurricane Sends Decade Old U.S.-Antigua Gambling Dispute back Into Spotlight, A Report of Council on Hemispheric Affairs (Aug. 20, 2018), available at http://www.coha.org/wp-content/uploads/2018/08/Lumsden-Piece.pdf (last visited on Jan. 19, 2019).

33. Appellate Body Report, United States - Measures Affecting the Cross-Border Supply of Gambling and Betting Services, WTO Doc. WT/DS285/AB/R (adopted Apr. 7, 2005).

34. Id. $\uparrow \uparrow \mid 208 \& 212$.

35. Id.

36. Supra note 31, ๆ 6.599.

37. Supra note 33, 9 甲 $351-356$ \& 371.

38. Panel Report, China - Measures Affecting Trading Rights and Distribution Services for Certain Publications and Audiovisual Entertainment Products, WTO Doc. WT/ DS363/R, ๆ 7.1209, (Aug. 12, 2009), available at https://docs.wto.org/dol2fe/Pages/FE_ Search/MultiDDFDocuments/78427/Q/WT/DS/363R-00.pdf;Q/WT/DS/363R-01.pdf (last visited on Jan. 19, 2019). In examining the definitions in Article XXVIII(b) of the GATS, it is noted that "the supply of a service" is defined as including the "production, 
distribution, marketing, sale and delivery of a service." [Emphasis added] This definition makes clear that the activity of 'distribution' is included within the notion of the supply of a service. Since a 'service' is intangible and not itself a good, this definition suggests that the supply of a service listed in a Member's Schedule, unless otherwise specified, can cover the distribution of non-physical products, such as sound recordings delivered over the Internet.

39. Appellate Body Report, China - Measures Affecting Trading Rights and Distribution Services for Certain Publications and Audiovisual Entertainment Products, WTO Doc. WT/DS363/AB, ๆๆ 392-394 (adopted Dec. 21, 2009).

40. The US-Mexico-Canada Trade Agreement, ch. 19 (Digital Trade), available at https:// ustr.gov/sites/default/files/files/agreements/FTA/USMCA/Text/19_Digital_Trade.pdf (last visited on Jan. 19, 2019).

41. Id. art. 19.4.2.

42. Id. art. 19.1

43. Id.

44. Id. art. 19.3.

45. The act, which has the purpose of promoting universal access and less burdensome Internet tax policy, imposes a moratorium on all taxation of Internet access and on 'multiple' or 'discriminatory' taxes on e-commerce. The act also includes a declaration that the Internet should be free of tariffs, trade barriers, and other restrictions. Moreover, the act asks the US President to pursue 'international agreements' to ban such tariffs and other trade barriers. See Internet Tax Freedom Act of 1998, 47 U.S.C. $§ 151$ (2000). The moratorium begins on October 1, 1998 and ends on November 1, 2003.

46. USMCA arts. $19.2 \& 19.5$.

47. G. Tassey, Standardization in Technology-based Markets 6-7 (1999), available at https:/www.nist.gov/sites/default/files/documents/2017/05/09/researchpolicypaper.pdf (last visited on Jan. 19, 2019).

48. USMCA art. 19.6.

49. Id. art. 19.4.1.

50. Id. art. 19.4.2.

51. Id. art. 19.7. The consumer protection provisions apply online and do not help consumers enforce their rights across borders.

52. Id. art. 19.8 .

53. A. Chander, The Coming North American Digital Trade Zone (2018), available at https://www.cfr.org/blog/coming-north-american-digital-trade-zone (last visited on Jan. 19, 2019).

54. USMCA art. 19.9.

55. CHANDER, supra note 53.

56. USMCA art. 19.12. 
57. W. Rinehart, How the USMCA Affects Digital Trade, American Action Forum: Insight (Oct. 24, 2018), available at https://www.americanactionforum.org/insight/how-theusmca-affects-digital-trade (last visited on Jan. 19, 2019).

58. USMCA art. 19.4.

59. Id. art. 19.11.

60. Shakila Bu-Pasha, Cross-Border Issues under EU Data Protection Law with regards to Personal Data Protection, 26 Information \& Comm. Tech. L. 216 (2017).

61. Id.

62. USMCA art. 19.16.

63. Id. 19.6(2).

64. Id. art. 19.17. See also E. Asp, Section 512 of the Digital Millennium Copyright Act: User Experience and User Frustration, 103 Iowa L. REv. $762-5$ (2018).

65. Id. art. 19.18 . 
